\title{
NMD and microRNA expression profiling of the HPCX1 locus reveal MAGEC1 as a candidate prostate cancer predisposition gene
}

\author{
Henna Mattila', Martin Schindler', Jarkko Isotalo', Tarja Ikonen ${ }^{1}$, Mauno Vihinen², Hannu Oja ${ }^{3}$, Teuvo LJ Tammela ${ }^{4}$,
} Tiina Wahlfors ${ }^{1}$ and Johanna Schleutker ${ }^{1 *}$

\begin{abstract}
Background: Several predisposition loci for hereditary prostate cancer (HPC) have been suggested, including HPCX1 at Xq27-q28, but due to the complex structure of the region, the susceptibility gene has not yet been identified.

Methods: In this study, nonsense-mediated mRNA decay (NMD) inhibition was used for the discovery of truncating mutations. Six prostate cancer (PC) patients and their healthy brothers were selected from a group of HPCX1-linked families. Expression analyses were done using Agilent $44 \mathrm{~K}$ oligoarrays, and selected genes were screened for mutations by direct sequencing. In addition, microRNA expression levels in the lymphoblastic cells were analyzed to trace variants that might alter miRNA expression and explain partly an inherited genetic predisposion to $P C$.
\end{abstract}

Results: Seventeen genes were selected for resequencing based on the NMD array, but no truncating mutations were found. The most interesting variant was MAGEC1 p.Met1?. An association was seen between the variant and unselected $P C(O R=2.35,95 \% C l=1.10-5.02)$ and $H P C(O R=3.38,95 \% C l=1.10-10.40)$. miRNA analysis revealed altogether 29 miRNAs with altered expression between the PC cases and controls. miRNA target analysis revealed that 12 of them also had possible target sites in the MAGEC1 gene. These miRNAs were selected for validation process including four miRNAs located in the X chromosome. The expressions of 14 miRNAs were validated in families that contributed to the significant signal differences in Agilent arrays.

Conclusions: Further functional studies are needed to fully understand the possible contribution of these miRNAs and MAGECl start codon variant to PC.

\section{Background}

Prostate cancer is the most common form of cancer affecting men in the Western world. In Finland, there were 4234 new cancer cases diagnosed in 2008, and the incidence of prostate cancer (PC) was 82.9/100.000 [1]. In addition to age, a well-established risk factor for PC is a family history of the disease. In a large Scandinavian twin study [2], it was reported that approximately $40 \%$ of the risk for PC can be explained by heritable components. This proportion is the highest ever reported for a

\footnotetext{
* Correspondence: johanna.schleutker@uta.fi

${ }^{1}$ Institute of Biomedical Technology, University of Tampere and Centre for Laboratory Medicine, Tampere University Hospital, Tampere, Finland Full list of author information is available at the end of the article
}

common malignancy. Most of the genes that are involved in the causation of hereditary cancers have been identified by linkage analysis. Several linkage studies of hereditary prostate cancer (HPC) have been performed and the results have implicated many risk loci located on different chromosomes, which indicates a great heterogeneity of this disease [3]. One of the loci found by linkage analysis is HPCX1 (OMIM \%300147), which is located on chromosome Xq27-q28 [4]. This locus has proven to be important in the Finnish population [5] and the region around the best linkage marker was found to be in strong linkage equilibrium [6]. However, the susceptibility gene has not yet been identified because the chromosomal region has an extremely

\section{Biomed Central}

(c) 2011 Mattila et al; licensee BioMed Central Ltd. This is an Open Access article distributed under the terms of the Creative Commons Attribution License (http://creativecommons.org/licenses/by/2.0), which permits unrestricted use, distribution, and reproduction in any medium, provided the original work is properly cited. 
complex genomic structure with multiple gene duplications and inversions that have hampered conventional gene cloning methods [7]. The SPANX genes and LDOC1 at Xq27 have been considered to be the best positional candidate genes for $H P C X 1$, but no direct evidence for causative mutations in any of the genes studied have been detected $[8,9]$.

Mutations, especially nonsense mutations, in tumor suppressor genes (TSGs) are common in the development and progression of cancer. They give rise to inframe premature translation termination codons within the coding regions of genes and lead to truncated protein translation products. However, the identification of TSGs by classical cancer genetics methods is difficult and slow. In addition, RNA transcripts carrying nonsense mutations are usually targeted for degradation through nonsense-mediated decay (NMD) [10]. NMD is a complex process in mammalian mRNA metabolism, and its function is to eliminate faulty transcripts and control the expression of normal genes.

A conventional strategy for the identification of disease genes is to use microarrays to compare the levels of gene-specific mRNA expression between patient and control samples. However, identification of the mutated gene can be obscured by inter-individual variation and secondary changes in gene expression caused by the disease process. Noensie and Dietz [11] reported an alternative strategy that circumvents these limitations, called GINI (Gene Identification by NMD Inhibition), in which the patient sample is compared to itself after the pharmacological inhibition of NMD. Microarrays are then used to identify potential nonsense transcripts that are increased in abundance after the loss of NMD. Emetine was used to block the pathway, but was problematic as emetine induces a stress response that results in the upregulation of additional transcripts. Ionov et al. [12] combined the emetine treatment with actinomycin D, which effectively prevents the upregulation of stress response genes while still stabilizing mutant transcripts.

Inactivation of autosomal tumor suppressor genes is a two-step process involving the mutation of the target gene and the loss of the wild type allele. In lymphoblastoid cell lines established from patient samples, the normal wild type allele can mask the effect of a mutated allele. However, because males have only one X chromosome, there is only one allele of the $\mathrm{X}$ chromosomal germline genes. Therefore, truncated tumor suppressor mRNAs may be identified by using NMD method applied for RNA extracted from patients' lymphoblastoid cell lines.

Cancer is fundamentally a disease of disordered gene expression. Since no causative mutations have been identified from the transcribed genes of the HPCX1 region, it is possible that the defect occurs at the regulatory level. Regulatory defects might also explain the relatively late onset of the disease, assuming a polygenic model for PC development with additive effect to the phenotype. MicroRNAs (miRNAs) are small RNA molecules that regulate gene expression post-transcriptionally [13]. They play an important role in diverse biological processes and, accordingly, altered miRNA expression is likely to contribute to human disease, including cancer. It has been shown that miRNA profiles are surprisingly informative. They become altered with the development and progression of PC [14] and have a very important role in the biology of the disease [15]. Since considerable amount of miRNAs are located within intronic regions and regulated by the host gene promoter [16], miRNA expression profiles give us one possibility to study disease related variations in non-protein coding chromosomal areas and this could lead to identification of regulatory variants especially in region with complex genomic structure like one in chromosome X.

Here, we present a study with Finnish multiplex HPCX1 linked families in which we have characterized the HPCX1 locus by NMD and miRNA microarray methods and evaluated the role of HPCX1 in the causation of familial prostate cancer.

\section{Methods}

\section{Study population}

\section{NMD microarray analysis}

Collection of the Finnish families with $\mathrm{PC}$ has been reported previously [5]. Based on the first linkage to HPCX1 in Finland [5], six affected and six healthy males for controls were selected from the linked families for NMD microarray analysis. Controls were the oldest healthy brothers of the affected males. The clinical characteristics of the patients are described in Table 1.

\section{miRNA microarray analysis}

For the miRNA microarray analysis, the original number of HPCX1-linked families was increased by seven based on recent linkage analysis [17]. As in the NMD study, the oldest possible healthy brother of the affected males was chosen as the control. The clinical characteristics of the patients are described in Table 1 .

\section{Association analysis}

The P.Met1? variant was analyzed in the youngest affected patient from $163 \mathrm{HPC}$ families, 757 patients with unselected PC, 757 healthy male blood donors, 764 healthy female blood donors, 375 men with benign prostate hyperplasia $(\mathrm{BPH})$, and 746 men who had a PSA level of less than $1.0 \mathrm{ng} / \mathrm{ml}$ (PSA controls). Collection of the Finnish families with $\mathrm{PC}$ has been reported previously [5]. In brief, families used in the association study had two or more first- or second-degree affected 
Table 1 Demographic, clinical, and pathological characteristics of the patients in microarray analyses

\begin{tabular}{|c|c|c|c|c|c|c|c|}
\hline Patient & Diagnosis age & Gleason score & WHO grade & $T^{*}$ & $\mathrm{~N}^{+}$ & $M^{\neq}$ & Primary $\mathrm{PSA}^{\S}$ \\
\hline $015-001^{* *}$ & 53 y $7 \mathrm{~m}$ & n.a. & $\|$ & T1c & $\mathrm{Nx}$ & MO & n.a. \\
\hline $043-001^{* *}$ & 50 y $9 \mathrm{~m}$ & 6 & $\|$ & $\mathrm{T} 2$ & $\mathrm{Nx}$ & MO & 3.8 \\
\hline $232-001^{* *}$ & 70 y 7 m & 7 & $\|$ & T1c & $\mathrm{Nx}$ & MO & 6.2 \\
\hline $232-002^{* *}$ & 75 y $5 \mathrm{~m}$ & n.a. & n.a. & T1a & $N x$ & MO & 1.3 \\
\hline $248-006^{* *}$ & 59 y $3 \mathrm{~m}$ & 6 & 1 & T1c & $\mathrm{Nx}$ & MO & 2.9 \\
\hline $311-003^{* *}$ & 60 y 4 m & 6 & $\|$ & $\mathrm{T} 2$ & $\mathrm{Nx}$ & MO & 21.9 \\
\hline 001-002 & 71 y 8 m & n.a. & $\|$ & T3 & Nx & MO & n.a. \\
\hline 292-010 & 47 y 11 m & 6 & $\|$ & $\mathrm{T} 2$ & Nx & $M x$ & 5.2 \\
\hline 408-002 & 67 y 5 m & 7 & $\|$ & T1c & $N x$ & $M x$ & 5.5 \\
\hline 236-006 & 75 y 11 m & n.a. & n.a. & T3 & $\mathrm{Nx}$ & $M x$ & 85 \\
\hline 402-003 & 67 y 3 m & 6 & 1 & $\mathrm{~T} 2$ & $\mathrm{Nx}$ & Mo & 13 \\
\hline 402-001 & 67 y $11 \mathrm{~m}$ & 7 & $\|$ & T1c & Nx & MO & 15 \\
\hline 413-003 & 55 y 3 m & 7 & $\|$ & T1c & Nx & MO & 6.4 \\
\hline 362-001 & 50 y $7 \mathrm{~m}$ & 6 & 1 & T1b & $\mathrm{Nx}$ & MO & 6.9 \\
\hline 362-002 & 49 y $4 \mathrm{~m}$ & 6 & I & $\mathrm{T} 1 \mathrm{c}$ & $\mathrm{Nx}$ & $M x$ & 41.9 \\
\hline
\end{tabular}

*The size of the tumor

${ }^{\dagger}$ Regional lymph nodes

${ }^{\ddagger}$ Distant metastases

${ }^{\S}$ Prostate specific antigen

**Patients in the NMD array

relatives. The mean number of affected relatives was 2.8 (range 2-7) and the mean age at diagnosis for the probands was 63.0 years (range 43-86). The youngest affected individual from each family was initially used in the association analysis. The unselected cases included consecutive patients diagnosed with PC in the Pirkanmaa Hospital District from 1999-2001. The mean age at diagnosis of the men with unselected PC was 69.0 years (range 45-93). The men with BPH were also patients from the Pirkanmaa Hospital District. The diagnosis of $\mathrm{BPH}$ was based on lower urinary tract symptoms, free uroflowmetry, and evidenced by palpation or transrectal ultrasound of increased prostate size. If PSA was elevated, then the patients underwent biopsies to exclude PC. The indication for biopsy was a total PSA level of $\geq$ $4 \mathrm{ng} / \mathrm{ml}$ or a total PSA level of 3.0-3.9 $\mathrm{ng} / \mathrm{ml}$ with the proportion of free PSA $<16 \%$. The mean age of the $\mathrm{BPH}$ patients was 73 years. The PSA controls were from the Finnish population-based prostate cancer screening trial [18]. The mean age of the men was 67.5 years (range 64-74). The population controls consisted of DNA samples from anonymous male and female blood donors obtained from the Finnish Red Cross in Tampere.

Permission to collect and use blood samples and clinical data from prostate cancer patients was granted by the Institutional Review Board of Tampere University Hospital and City of Tampere. Written informed consent for use of their samples as well as medical records was obtained from all individuals participating in this study.

\section{Cell culture and drug treatments}

In the NMD microarray experiment, the cell lines were derived by Epstein-Barr virus transformation of peripheral mononuclear leukocytes from patients and their healthy brothers. Lymphoblastoid cell lines were grown in RPMI-1640 medium (Lonza, Walkersville, MD, USA) supplemented with $10 \%$ fetal bovine serum (SigmaAldrich, St. Louis, MO, USA) and antibiotics. The emetine treatment protocol was described previously [12]. Briefly, for each cell line, we treated half of the subconfluent cells with $100 \mu \mathrm{g} / \mathrm{ml}$ of emetine dihydrochloride hydrate (Fluka, Buchs, Switzerland) and the rest were used as untreated controls. Both the treated and untreated cells were incubated for $10 \mathrm{~h}$ at $37^{\circ} \mathrm{C}$. After this, actinomycin D (Sigma-Aldrich) was added to the treated and untreated cells, and they were incubated for $4 \mathrm{~h}$ at $37^{\circ} \mathrm{C}$. Cell pellets were snap-frozen and total RNA was extracted from treated and untreated cells with Trizol according to the manufacturer's instructions (Invitrogen, Carlsbad, CA, USA). In the miRNA microarray experiment, the lymphoblastoid cell lines were grown similarly as above, but without drug treatments. RNA yields were quantified using an ND-1000 spectrophotometer (Nanodrop Technologies, Wilmington, DE, USA).

\section{Oligonucleotide array protocol}

mRNA levels in the treated and untreated cells were measured using the Agilent $44 \mathrm{~K}$ array according to the manufacturer's instructions (Agilent Technologies, Inc., Santa Clara, CA, USA). Twenty micrograms of total 
RNA were used to generate fluorescent $\mathrm{Cy}$-3-labeled cRNA (control cells) and Cy-5-labeled cRNA (treated cells) using an Agilent Fluorescent Direct Label Kit. Labeled RNAs were pooled and hybridized to the Agilent $44 \mathrm{~K}$ Whole Human Genome Oligonucleotide Microarrays (Agilent Technologies) containing over 33,000 known and novel human genes ( 41,000 human genes and transcripts). A total of 12 arrays were hybridized, one for every individual. Microarray slides were scanned (Agilent microarray scanner) after hybridization, and data was extracted using Feature Extraction software, version A.7.5.1. (Agilent Technologies). For data analysis, the raw microarray expression values of the rMeanSignal and gMeanSignal variables were first background-adjusted and a natural logarithm of a ratio of the variables rMeanSignal and gMeanSignal was taken. The log-ratio values were normalized between arrays by using the quantile normalization method. A linear mixed model was then used as a method for identifying the set of differentially expressed genes in a considered experimental set-up. The normalized expression values of each gene at Xq27-28 were separately modeled by the linear mixed model that included the treatment effect (i.e., the affected person versus healthy) as a fixed effect and the family effect as a random effect. In the model analysis, a considered gene was declared differentially expressed if the calculated estimate for the parameter associated with the fixed treatment effect was greater than zero, and if, at the same time, the p-value in the t-test for the null hypothesis concerning the fixed effect parameter being zero was smaller than the cut-off value of 0.025 . The oligonucleotide microarray data have been deposited in NCBI's Gene Expression Omnibus http://www.ncbi.nlm.nih.gov/geo following the MIAME guidelines and are accessible through GEO series accession number GSE24205.

\section{Mutation screening and genotyping}

Mutation screening of the coding regions of selected genes and the genotyping of the P.Met1? mutation were performed by sequencing. Genomic DNA was extracted from peripheral blood samples using a commercially available kit (Puregene, Gentra Systems, Minneapolis, MN, USA). For sequencing analysis, PCR products were purified in 96-format Acro Prep Filter Plates (Pall Life Sciences, Ann Arbor, MI, USA) using the Perfect Vac Manifold vacuum machine (Eppendorf AG, Hamburg, Germany). Sequencing was performed according to the manufacturer's instructions using a BigDye Terminator v.3.1 Cycle Sequencing Kit and an automated ABI PRISM 3130xl Genetic Analyzer (Applied Biosystems, Foster City, CA, USA). Sequence analysis was done with Sequencher 4.2.2 software (Gene Codes Corporation, Ann Arbor, MI, USA).

\section{MicroRNA array protocol}

MicroRNA expression levels in lymphoblastoid cell lines were detected using an Agilent Human miRNA V2 Oligo Microarray Kit (Agilent Technologies). First, 100 ng of total RNA was used as a starting material, and miRNAs were labeled using the Agilent miRNA Labeling Kit. Labeled RNA was hybridized to Agilent miRNA arrays with eight identical arrays per slide, with each array containing probes directed against 723 human and 76 human viral miRNAs. Slides were scanned (Agilent microarray scanner) after hybridization and data was extracted using Feature Extraction software, version 9.5.1. (Agilent Technologies). For data analysis, low quality samples and non-expressed miRNAs were first removed ending up with 29 individuals from 9 families and with 333 miRNAs. Inside every family the directional distance of healthy individuals from patients was calculated. The distance used here was based on Kendal's tau $($ distance $=(1-$ tau $) / 2)$ and the distance between clusters was computed using Ward's method. By decomposing Kendal's tau into each miRNA's contribution the distance induced by every miRNA can be quantified separately. The direction of this distance inside every family is marked positive if the average rank miRNA expression for patients is higher than for healthy individuals and negative if the average rank miRNA expression for healthy individuals is higher than for patients. The overall directional distance for every miRNA is obtained by summing up these directional distances over all families. Then the permutation $\mathrm{p}$-value was computed by permuting healthy individuals and patients randomly inside every family, computing the overall directional distance, repeating this many times and the final permutation $\mathrm{p}$-value is the proportion of these permuted distances higher or lower than the original distance. The micro-RNA microarray data have been deposited in NCBI's Gene Expression Omnibus http:// www.ncbi.nlm.nih.gov/geo following the MIAME guidelines and are accessible through GEO series accession number GSE24205.

\section{MicroRNA target detection}

The miRanda algorithm [19] was used for finding genomic targets for miRNAs. For each miRNA, target genes were selected on the basis of three properties: sequence complementarity using a position-weighted local alignment algorithm, free energies of RNA-RNA duplexes, and conservation of target sites in related genomes. All of the human miRNA sequences were downloaded from the Sanger Institute miRBase [20], and they were aligned with the genomic sequences of variant sites from the sequenced genes. The aim was to identify miRNA target sites that either appear or disappear due to variants. Based on the total score value given to every wild type 
and mutant sequence combination by the miRanda algorithm, the difference between values was calculated. The top $5 \%$ of the highest differences were selected for further analysis.

\section{miRNA expression validation}

Expression of miRNAs in the lymphoblastoid cell lines was validated by the specific TaqMan MicroRNA assays according to the manufacturer's instructions (Applied Biosystems). TaqMan microRNA assays were performed using Bio-Rad Laboratories' CFX384 real-time PCR detection system with the Bio-Rad C1000 thermal cycler (Bio-Rad Laboratories, Inc., US).

\section{Statistical analyses}

Distribution of the genotypes and alleles, the odds ratio (OR), and the 95\% confidence interval (CI) were calculated with the SPSS statistical software package, version 15.0 (SPSS, Chicago, IL). Associations with demographic, clinical, or pathological features of the disease (age at diagnosis, PSA value at diagnosis, T-stage, WHO grade, and Gleason score) were tested among unselected PC and HPC cases using R software http://www.r-project.org.

\section{Results}

In order to identify genes containing inactivating mutations in the Xq27-q28 region, an NMD microarray analysis with Agilent $44 \mathrm{~K}$ Whole Human Genome oligonucleotide microarrays was performed in the families showing the strongest linkage to HPCX1. The candidate genes $(n=17)$ for subsequent sequence analysis were selected according to the microarray analysis
(RBMX, CSAG2, RAP2C, SOX3, MBNL3, ZNF75, MAGEC1, MAGEA1, MAGEA11, MAGEC3, MAGED1, U66046, SSR4, VBP1, LDOC1, TKTL1, CD4OLG) (Table $2)$. All identified stress response genes were excluded [21]. No truncating mutations were detected, but a total of 34 changes were found by direct sequencing. Eight of the changes were missense variants, six were silent changes, and twenty of the variants took place in introns, 5'UTR, or 3'UTR regions. Twenty of the changes were novel and not found in any genomic databases. A summary of the identified variants is presented in Table 3.

The most interesting variation selected for follow-up was the MAGEC1 p.Met1? (c.2T > C; Met > Thr) start codon mutation found in family 311 . The frequency of that mutation was determined by sequencing among patients with unselected PC or HPC and in the control groups. The carrier frequencies for p.Met1? were $2.45 \%$, $1.72 \%, 0.92 \%, 0.53 \%, 1.21 \%$, and $0.65 \%$ in the probands with $\mathrm{HPC}$, unselected PC cases, male population controls, BPH controls, PSA controls, and female population controls, respectively. The frequency of P.Met1? was found to be in Hardy-Weinberg equilibrium in controls. A statistically significant difference was observed in the carrier frequencies of the P.Met1? variant between the sample groups, and an association was seen between the variant and unselected PC and HPC (see Table 4). The association was strongest when male and female blood donors and BPH patients were used as a control group $(\mathrm{OR}=2.35,95 \% \mathrm{CI}=1.10-5.02$ for unselected $\mathrm{PC}$; $\mathrm{OR}=3.38,95 \% \mathrm{CI}=1.10-10.40$ for $\mathrm{HPC}$ ). The association between the frequency of the variant and the disease phenotype, including tumor WHO

Table 2 Genes selected for resequencing based on NMD oligoarray analysis

\begin{tabular}{|c|c|c|c|c|}
\hline Gene ID & Gene name & Cytogenetic band & Genomic location (strand) & Selection criteria \\
\hline$R B M X$ & RNA binding motif protein, $X$-linked & Xq26.3 & $135951351-135962939$ bp (-) & $\mathrm{p}<0.05$ \\
\hline CSAG2 & Homo sapiens CSAG family, member 2 & $X q 28$ & $151922445-151928738$ bp (+) & $p<0.05$ \\
\hline RAP2C & Homo sapiens RAP2C, member of RAS & $X q 25$ & 131337 053-131353 471 bp (-) & $p<0.05$, fold change $>1.5$ \\
\hline SOX3 & SRY (sex determining region Y)-box 3 & $X q 27.1$ & 139585 152-139 587225 bp (-) & $p<0.05$ \\
\hline MBNL3 & Muscleblind-like 3, (Drosophila) & $X q 26.2$ & $131506029-131623996$ bp (-) & $p<0.05$ \\
\hline ZNF75 & Zinc finger protein 75 & Xq26.3 & $134382867-134478012$ bp (-) & $p<0.05$ \\
\hline MAGEC1 & Melanoma antigen family C, 1 & $\mathrm{Xq} 26$ & 140991 680-140997 183 bp (+) & $p<0.05$ \\
\hline MAGEA1 & Melanoma antigen family A, 1 & $\mathrm{Xq} 28$ & $152481522-152486116$ bp (-) & $p<0.05$, fold change $>1.5$ \\
\hline MAGEA11 & Melanoma antigen family A, 11 & $\mathrm{Xq} 28$ & 148769 894-148,798,928bp (+) & location \\
\hline MAGEC3 & Melanoma antigen family C, 3 & $\mathrm{Xq} 27.2$ & $140926102-140985618$ bp (+) & location \\
\hline MAGED1 & Melanoma antigen family $D, 1$ & Xp11.23 & $51546103-51645453$ bp (+) & $p<0.05$ \\
\hline U66046 & hypothetical protein FLJ44451 & $\mathrm{Xq} 28$ & $148615451-148616127$ bp (-) & $p<0.05$ \\
\hline SSR4 & signal sequence receptor, delta & Xq28 & $153058971-153063960$ bp (+) & $p<0.05$ \\
\hline VBP1 & von Hippel-Lindau binding protein 1 & Xq28 & 154444 550-154 468098 bp (+) & $\mathrm{p}<0.05$ \\
\hline LDOC 1 & leucine zipper, down-regulated in cancer, 1 & $\mathrm{Xq} 27$ & 140269 930-140 271310 bp (-) & $p<0.05$ \\
\hline TKTL 1 & transketolase-like 1 & Xq28 & 153524 024-153 558700 bp (+) & $p<0.05$ \\
\hline CD4OLG & CD40 ligand & $X q 26$ & 135730 336-135 742549 bp (+) & $p<0.05$ \\
\hline
\end{tabular}


Table 3 Summary of variants found in the HPCX1 region from Finnish HPC families

\begin{tabular}{|c|c|c|c|}
\hline Gene & Variation* & Amino acid change & $\mathrm{dbSNP}$ \\
\hline CD4OLG & c. $148 \mathrm{~T}>\mathrm{C}$ & p.Leu50Ser & rs1126535 \\
\hline LDOC 1 & c. $-62 C>G$ & - & - \\
\hline \multirow[t]{5}{*}{ MAGEA1 } & c.- $-2924 G>T$ & - & - \\
\hline & c. $-264, G>A$ & - & - \\
\hline & $\mathrm{c} .813 \mathrm{C}>\mathrm{T}$ & p.Leu271 & rs2233045 \\
\hline & $c^{*} 17 A>G$ & - & - \\
\hline & $c{ }^{*} 477 C>T$ & - & - \\
\hline \multirow[t]{5}{*}{ MAGEA11 } & $c .96+38 \mathrm{~A}>\mathrm{G}$ & - & - \\
\hline & c.193-64T > C & - & - \\
\hline & c. $266+10 \mathrm{C}>\mathrm{T}$ & - & - \\
\hline & c.1077 C > T & p.Leu359 & - \\
\hline & C. ${ }^{*} 234 \mathrm{~T}>\mathrm{C}$ & - & - \\
\hline \multirow[t]{11}{*}{ MAGEC1 } & c. $-2051 G>A$ & - & - \\
\hline & c. $-2008 \mathrm{~T}>\mathrm{C}$ & - & rs1003682 \\
\hline & $\mathrm{c} .2 \mathrm{~T}>\mathrm{C}$ & P.Met1? & - \\
\hline & c.5-44T > C & - & - \\
\hline & $c .74 G>A$ & p.Cys25Tyr & rs176036 \\
\hline & c. $452 \mathrm{C}>\mathrm{T}$ & p.Thr151lle & rs176037 \\
\hline & c. $1327 \mathrm{C}>\mathrm{G}$ & p.Leu443Val & rs62611966 \\
\hline & c. $1401 C>G$ & p.His467Gln & rs176048 \\
\hline & c. $2125 \mathrm{C}>\mathrm{T}$ & p.His709Tyr & rs56256227 \\
\hline & c. $3174 G>A$ & p.Glu1058 & rs12845617 \\
\hline & $C .53 C>T$ & - & rs41300301 \\
\hline \multirow[t]{5}{*}{ MAGEC3 } & c. $-189 \mathrm{C}>\mathrm{T}$ & - & - \\
\hline & c. $259-66 G>A$ & - & - \\
\hline & c.259-15T > C & - & - \\
\hline & $c .880 C>G$ & p.Leu294Val & - \\
\hline & c.958C > T & p.Leu320 & rs176025 \\
\hline$M B N L 3$ & $c .923-11 G>A$ & - & - \\
\hline$R B M X$ & C. $-1 C>A$ & - & rs2011584 \\
\hline \multirow[t]{3}{*}{ SUHW3 } & c. $1851 \mathrm{~A}>\mathrm{C}$ & p.Gly617 & rs209238 \\
\hline & c. $2161+4 C>T$ & - & - \\
\hline & c. $2162-41 \mathrm{~T}>\mathrm{C}$ & - & - \\
\hline ZNF75 & c. $1434 \mathrm{G}>\mathrm{A}$ & p.Thr478 & rs1129093 \\
\hline
\end{tabular}

*Numbering is according to the cDNA starting at the A in the start codon.

grade, Gleason score, T-stage, age at diagnosis, and PSA value at diagnosis, was also analyzed among the unselected PC cases as no complete data were available for the HPC cases. No significant associations were found from these studies (data not shown). Additional samples from three prostate cancer families carrying the p.Met1? variant were also analyzed, but cosegregation of the $\mathrm{p}$. Met1? was incomplete (data not shown) which is quite expected for a low penetrance gene.

MicroRNA expression levels in lymphoblastoid cell lines were determined with Agilent Human miRNA arrays. The most differentially expressed miRNAs when testing against both alternatives (miRNA expression is either up- or downregulated in case vs. controls) are
Table 4 Association of the MAGEC1 P.Met1? variant with unselected PC or HPC

\begin{tabular}{lccc}
\hline Sample group & $\begin{array}{c}\text { Carrier } \\
\text { frequency }\end{array}$ & OR (95\% Cl) & P \\
\hline Male population controls & $7 / 757(0.92 \%)$ & 1.00 & \\
Female population & $5 / 764(0.65 \%)$ & 1.00 & \\
controls & $2 / 375(0.53 \%)$ & 1.00 & \\
Patients with BPH & $9 / 746(1.21 \%)$ & 1.00 & \\
PSA controls & $13 / 757(1.72 \%)$ & $1.99(1.00-3.95)^{*}$ & $0.04^{*}$ \\
Patients with unselected & & $2.35(1.10-5.02)^{* *}$ & $0.02^{* *}$ \\
PC & $4 / 163(2.45 \%)$ & $2.86(0.98-8.38)^{*}$ & $0.04^{*}$ \\
& & $3.38(1.10-10.40)$ & $0.02^{* *}$ \\
Patients with HPC & & $* *$ &
\end{tabular}

*Male and female blood donors, BPH patients, and PSA controls used as a control group.

**Male and female blood donors and BPH patients used as a control group.

presented in Table 5 and 6 together with information about genomic and intronic/intergenic location. The miRanda algorithm produced 1211 different variantmiRNA combinations with a total score value above the cut-off value. From the 29 differentially expressed miRNAs between patients and healthy individuals twelve miRNAs for validation were selected based on that they supposedly had a target site in MAGEC1 gene (Table 5 and 6). In addition, miRNAs located in X chromosome were selected for validation. Validation of these selected miRNA expressions in cell lines was based on specific TaqMan MicroRNA Assays (Tables 5 and 6, Figures 1, 2 and 3$)$.

\section{Discussion}

The recognition that PC clusters within families has led to the collection of HPC families with the goal of localizing and identifying PC susceptibility genes. Initially, the PC susceptibility locus, HPCX1, was mapped to the $\mathrm{X}$ chromosome by using a set of high-risk $\mathrm{PC}$ families from the United States, Finland, and Sweden. The effect of $H P C X 1$ was proven to be the most important in the Finnish population, where a specific haplotype in the region was also identified [5,6]. Further, X-chromosomal inheritance coheres with the results of our segregation analysis of multifactorial recessive inheritance as the only model in the Finnish population [22]. In this study, a recently developed NMD microarray technology was utilized for the analysis of the HPCX1 region with brother pairs from $H P C X 1$ linked families. Use of the unaffected brothers as controls might be problematic given the late age of prostate cancer diagnosis, but the unaffected brothers were chosen to be the oldest possible from every family with no history of PC. Previously, the manipulation of NMD together with expression array analysis has proven to be a powerful tool for 
Table 5 Differentially expressed miRNAs between patients and healthy individuals: Testing against alternative that a miRNA is upregulated in patients

\begin{tabular}{|c|c|c|c|c|c|}
\hline $\begin{array}{l}\text { Mature } \\
\text { miRNA }^{1}\end{array}$ & $\begin{array}{l}\mathrm{p}- \\
\text { value }\end{array}$ & $\begin{array}{l}\text { Pre-miR miRBase } \\
\text { ID }\end{array}$ & Location & $\begin{array}{l}\text { Possible target site in } \\
\text { MAGEC1 }\end{array}$ & Validation (TaqMan) \\
\hline hsa-miR-296-5p & 0.0049 & MI0000747 & chr 20: intronic (AL136532) & & \\
\hline hsa-miR-766 & 0.0157 & MI0003836 & chr X: intronic (SEPT6) & & + (in families $1,15,232,362$ ) \\
\hline $\begin{array}{l}\text { hsa-miR-767- } \\
3 p\end{array}$ & 0.0189 & MI0003763 & chr X: intronic (GABRA3) & & $\begin{array}{l}+(\text { in families } \\
1,15)\end{array}$ \\
\hline $\begin{array}{l}\text { hsa-miR-151- } \\
5 p\end{array}$ & 0.0312 & MI0000809 & chr 8: intronic (PTK2) & $\begin{array}{l}\text { C.5-44T }>C \\
\text { c. }{ }^{*} 53 C>T\end{array}$ & $+($ in family 1$)$ \\
\hline \multirow[t]{2}{*}{ hsa-miR-133a } & 0.0316 & $\begin{array}{l}\text { 133a-1: } \\
\text { MI0000450 }\end{array}$ & chr 18: intronic (MIB1) & c.74G > A & + (in family 15 ) \\
\hline & & $\begin{array}{l}\text { 133a-2: } \\
\text { MI0000451 }\end{array}$ & $\begin{array}{l}\text { chr 20: intronic } \\
\text { (C20orf166) }\end{array}$ & & \\
\hline hsa-miR-451 & 0.0319 & MI0001729 & chr 17: intergenic & c. $1327 \mathrm{C}>\mathrm{G}$ & + (in family 1 ) \\
\hline hsa-miR-23b & 0.0393 & MI0000439 & chr 9: intronic (C9orf3) & $\begin{array}{l}\text { c. } 452 C>\mathrm{T} \\
\text { c. } 1327 \mathrm{C}>\mathrm{G}\end{array}$ & + (in families $1,15,413$ ) \\
\hline hsa-miR-223 & 0.0404 & MI0000300 & chr X: intergenic & & + (in families $1,15,362,413$ ) \\
\hline hsa-miR-146a* & 0.0404 & MI0000477 & chr 5: intergenic & & \\
\hline $\begin{array}{l}\text { hsa-miR-342- } \\
5 p\end{array}$ & 0.0410 & MI0000805 & chr 14: intronic $(E V L)$ & c. $452 C>T$ & $\begin{array}{l}+ \text { (in families 248, 292, 402, 408, } \\
413 \text { ) }\end{array}$ \\
\hline hsa-miR-183* & 0.0433 & MI0000273 & chr 7: intergenic & & \\
\hline $\begin{array}{l}\text { hsa-miR-151- } \\
3 p\end{array}$ & 0.0438 & MI0000809 & chr 8: intronic (PTK2) & $\begin{array}{l}\text { C.5-44T }>C \\
\text { c. }{ }^{5} 53 \mathrm{C}>\mathrm{T}\end{array}$ & + (in families 1,402 ) \\
\hline hsa-miR-129-3p & 0.0465 & MI0000473 & chr 11: intergenic & & \\
\hline hsa-miR-129* & 0.0477 & MI0000252 & chr 7: intergenic & & \\
\hline
\end{tabular}

${ }^{1}$ miRNAs selected for validation are represented in bold

detecting novel gene mutations in cancer cells. Huusko et al. [23] successfully identified EPHB2 gene mutations in PC. Since then, mutations in melanoma cell lines [24], colon cancer cell lines [25], and PC cell lines [26] have been identified by inhibition of NMD.
Sequencing of 17 genes from the HPCX 1 region did not reveal any truncating nonsense mutations. The most interesting variation for follow-up was in the start codon (p.Met1?) of the MAGEC1 gene. An association was later seen between the p.Met1? variant and

Table 6 Differentially expressed miRNAs between patients and healthy individuals: Testing against alternative that a miRNA is downregulated in patients

\begin{tabular}{|c|c|c|c|c|c|}
\hline Mature miRNA ${ }^{1}$ & p-value & Pre-miR miRBase ID & Location & Possible target site in MAGEC1 & Validation (TaqMan) \\
\hline hsa-miR-32 & 0.0001 & MI0000090 & chr 9: intronic (C9orf5) & c. ${ }^{*} 53 \mathrm{C}>\mathrm{T}$ & + (in families 1,248 ) \\
\hline hsa-miR-30a & 0.0102 & MI0000088 & chr 6: intronic (C6orf155) & & \\
\hline hsa-miR-33a & 0.0184 & MI0000091 & chr 22: intronic (SREBF2) & & \\
\hline hsa-miR-345 & 0.0210 & MI0000825 & chr 14: intergenic & & \\
\hline hsa-miR-195 & 0.0245 & MI0000489 & chr 17: intronic $(A C 027763)$ & c. $* 53 \mathrm{C}>\mathrm{T}$ & + (in families $292,362,408$ ) \\
\hline hsa-miR-487b & 0.0279 & MI0003530 & chr 14: intergenic & c. ${ }^{*} 53 \mathrm{C}>\mathrm{T}$ & + (in families 248,292 ) \\
\hline hsa-miR-370 & 0.0292 & MI0000778 & chr 14: intergenic & & \\
\hline hsa-miR-770-5p & 0.0305 & MI0005118 & chr 14: intronic (MEG3) & c.3174G > A & - \\
\hline hsa-miR-29c & 0.0330 & MI0000735 & chr 1: intergenic & $\begin{array}{l}\mathrm{c} .1327 \mathrm{C}>\mathrm{G} \\
\mathrm{c} .2125 \mathrm{C}>\mathrm{T}\end{array}$ & + (in families $1,248,362$ ) \\
\hline hsa-miR-34c-3p & 0.0351 & MI0000743 & chr 11: intergenic & & \\
\hline hsa-miR-148a & 0.0426 & MI0000253 & chr 7: intergenic & & \\
\hline hsa-miR-20b & 0.0431 & MI0001519 & chr X: intergenic & & + (in family 1 ) \\
\hline \multirow[t]{2}{*}{ hsa-miR-29b } & 0.0478 & 29b-1: MI0000105 & chr 7: intronic (AC016831) & & \\
\hline & & 29b-2: MI0000107 & chr 1: intergenic & & \\
\hline hsa-miR-212 & 0.0482 & MI0000288 & chr 17: intergenic & c.3174G > A & - \\
\hline \multirow[t]{3}{*}{ hsa-miR-7 } & 0.0490 & 7-1: MI0000263 & chr 9: intronic (HNRNPK) & & \\
\hline & & 7-2: MI0000264 & chr 15: intergenic & & \\
\hline & & 7-3: MI0000265 & chr 19: intronic (C19orf30) & & \\
\hline
\end{tabular}

${ }^{1}$ miRNAs selected for validation are represented in bold 

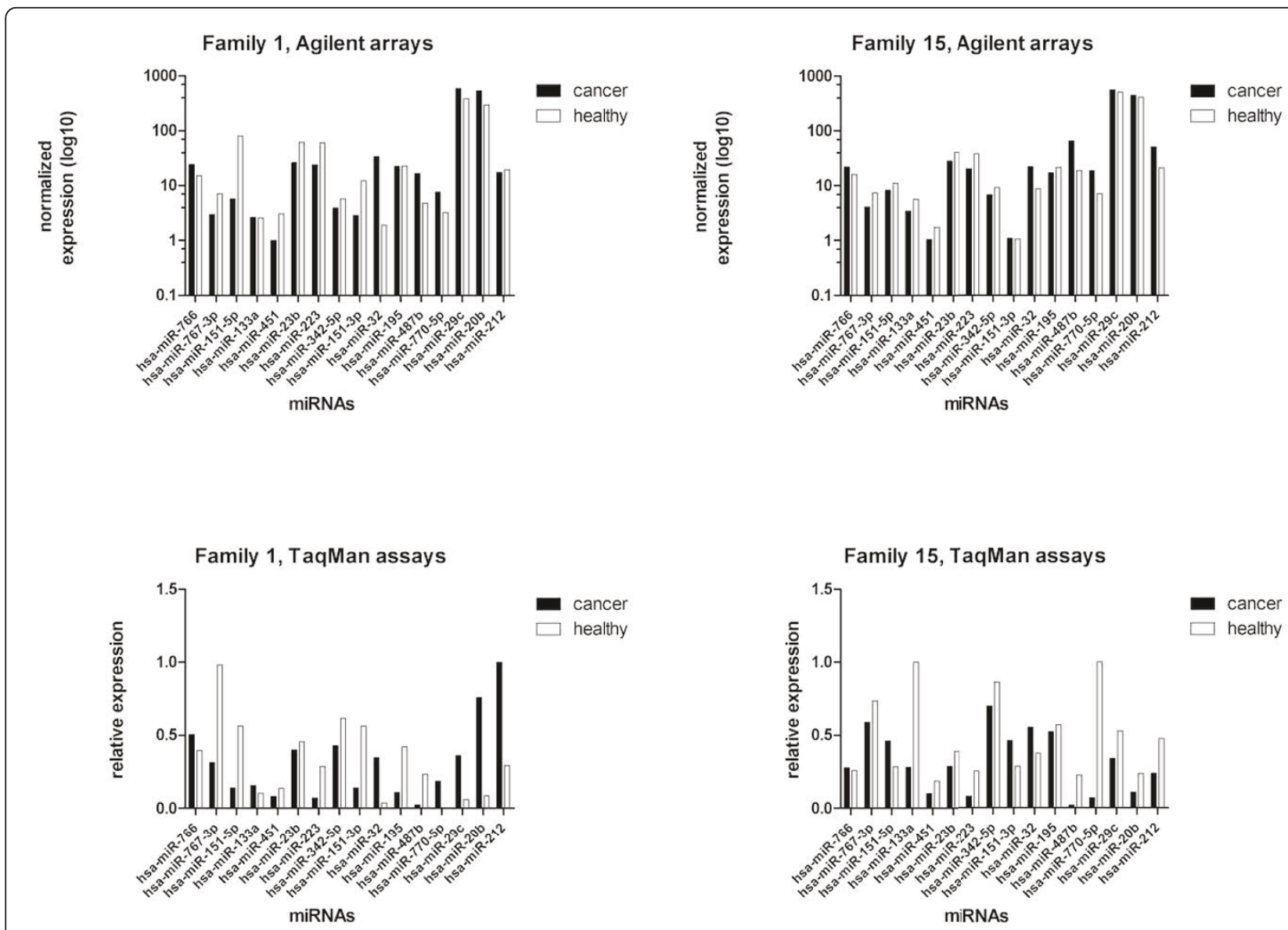

Figure 1 Validation of miRNA expressions in families 1 and 15. In the upper row the normalized expressions of sixteen miRNAs are presented (black bars indicate cancer patients and white bars indicate healthy brothers). In the lower row the corresponding expression values measured with specific TaqMan miRNA assays are displayed.

unselected PC and HPC. Interestingly, the association was strongest when "supernormal" PSA controls were excluded from the control group. The PSA controls consisted of men with PSA levels $<1.0 \mathrm{ng} / \mathrm{ml}$ and a mean age of 67.5 years, which is lower than the mean age of BPH patients (73 years). As HPCX1 is suggested to be a late-onset disease in the Finnish population [5], as well as in some other populations [27], it is possible that the younger PSA control group is actually more saturated with the p.Met1? individuals who are at risk of developing late-onset HPCX. MAGEC1 is a member of the melanoma antigen gene (MAGE) family [28]. The proteins of this family are tumor-specific antigens that can be recognized by autologous cytolytic $\mathrm{T}$ lymphocytes. MAGEC1 is composed of four exons and encodes a protein of 1142 amino acids. It is approximately 800 residues longer than other MAGE proteins due to the insertion of a large number of short repetitive sequences in front of the MAGE-homologous sequence. MAGEC1 is expressed in a significant proportion of tumors of various histological types, but is silent in normal tissues, excluding the testis. Alternative start codons, mainly GTG and TTG, are used in prokaryotes and, very rarely, in higher organisms. One example is the vitamin-D receptor $(V D R)$ gene start codon polymorphism, where a $\mathrm{T} / \mathrm{C}$ polymorphism in the first of the two potential start (ATG) codons results in two alleles that can be distinguished by RFLP using the endonuclease FokI [29]. The biological function of the identified MAGEC1 start codon variant in this case is difficult to assess since we were not able to investigate the expression of MAGEC1 in individuals carrying the mutated allele in the absence of other tissue material. Considering the conserved structure and similar functions of MAGE proteins, it might be possible that other members of the gene family can partly compensate for the functions of MAGEC1 if the start codon mutation totally blocks the translation of the gene.

In this NMD array analysis, the false positive rate was evidently high since no truncating mutations were found. Emetine treatment followed by actinomycin D treatment was used, but it has been observed that treatment with 


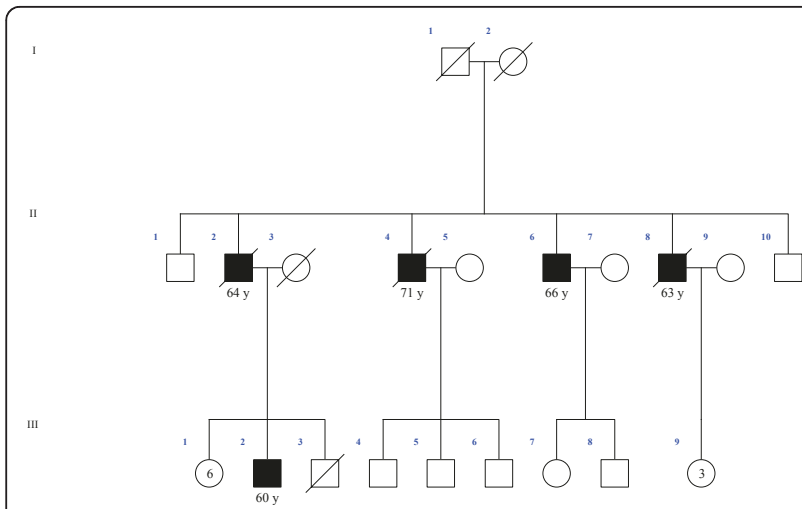

Figure 2 Pedigree of HPCX1 linked family 1 . Black square denotes persons with prostate cancer, black square and circle with white surroundings signifies patient with another type of cancer. Age at diagnosis for prostate cancer patients (in years) is indicated below the symbol. The pedigrees have been altered to protect anonymity.

actinomycin D after emetine incubation does not have a significant effect on treated cells, suggesting that the combination of the drugs is not the best possible method for this type of study [30]. A novel improvement to the NMD protocol includes a combination of emetine and caffeine treatment [25], which leads to a more efficient identification of false positives produced by cell stress. On the other hand, we might have missed genes that actually carry truncating mutations. If the genes were mutated both in the seemingly healthy males with a normal clinical phenotype and their already affected siblings, they would have had the same profile as the stress response genes and would have, therefore, been excluded. In addition, relevant variants might have been missed by being limited to use lymphoblastoid cell lines, as they may not resemble the whole set of active genes in prostate tissue. Although there is substantial amount of evidence that lymphoblastoid cells encompasses a variety of metabolic pathways that are specific to individuals where the cells originated, making these cell lines suitable for molecular and functional studies [31].

Despite its association with $\mathrm{PC}$, the segregation of the P.Met1? variant in studied families was incomplete. This finding can also reflect the high phenocopy rate of the disease, and as a consequence, even the most extreme families may have a few sporadic cases. Currently, there are no clinical or molecular tools to distinguish "true" HPC cases from sporadic ones. Therefore, the incomplete segregation does not necessarily diminish the importance of p.Met1? as a HPCX1 risk variant.

The number of publications reporting differential miRNA expression in prostate cancer is constantly growing. Analyses have been performed for example in clinical prostate specimens [32], and in PC cell lines, xenografts, $\mathrm{BPH}$ vs. $\mathrm{PC}$ samples [33]. Most recently, miRNA expression profiles of androgen-responsive and castrate-resistant PC cell lines were compared [34]. In all of these studies, a set of 20-30 miRNAs unequivocally differentiated the PC samples from the normal samples and nonmalignant precursor lesions, and specific miRNAs including miR-125b, miR-145, and let-7c were repeatedly detected differentially expressed in different studies.

In the current study, we hypothesized that miRNA profiling could be used as a tool for discovering variants from non-protein coding regions which could explain the "dark" inheritance behind HPCX. Altered miRNA expression in patients lymphoblastoid cells could lead to the identification of germline variants in promoter or other regulatory regions of protein coding genes since considerable amount of miRNA expression is correlated to host and target gene expression [35]. Possible explanation of differences in miRNA levels could be their role in tumor development and initiation. Already, several studies have shown that miRNAs

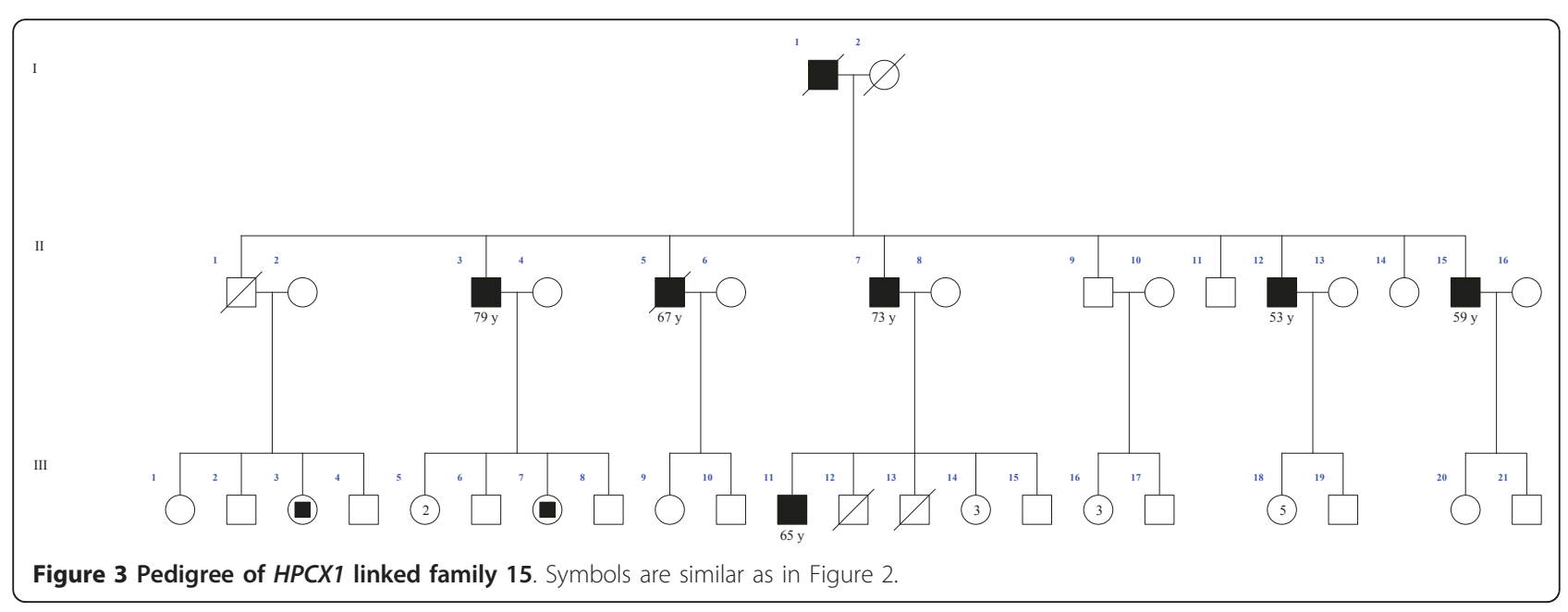


in serum can be considered as biomarkers [36,37] and serum miRNAs are mainly derived from circular blood cells [38], the same way as lymphoblastoid cells. We were able to identify 29 significantly differently expressed miRNAs between patients and their healthy brothers. Validation of the expressions of the selected 16 miRNAs with TaqMan assays were successful in $14 / 16$ cases, including all four miRNAs located in the $\mathrm{X}$ chromosome.

\section{Conclusions}

In conclusion, we suggest a role for $M A G E C 1$ in genetic PC susceptibility, especially in the HPCX1-linked form of the disease. The start codon missense variation in the $M A G E C 1$ gene showed a borderline association between the variant and both HPC and unselected PC, and therefore additional research is warranted. In addition, the role of certain miRNAs needs further study, especially since $M A G E C 1$ was predicted to be one of their targets.

\section{List of abbreviations used}

HPC: hereditary prostate cancer; NMD: nonsense-mediated mRNA decay; PC: prostate cancer; TSG: tumor suppressor gene; GINI: gene identification by NMD inhibition; BPH: benign prostate hyperplasia; PSA: prostate specific antigen

\section{Acknowledgements and funding}

We thank Maija Wolf and Olli Kallioniemi for providing instruction in the NMD array methodology, Minna Sjöblom and Linda Enroth for technical assistance, and Riitta Vaalavuo for assistance, as well as all of the prostate cancer patients and their families for their participation.

The present study was financially supported by Competitive Research Funding of the Tampere University Hospital (Grant 9K119), the Finnish Cancer Organisations, the Sigrid Juselius Foundation, the Academy of Finland (\#116437, \#118413) and the Reino Lahtikari Foundation. The Ida Montin Foundation and the Orion-Farmos Research Foundation have financially supported H.M. and the Academy of Finland (\#126714) T.W.

\section{Author details}

'Institute of Biomedical Technology, University of Tampere and Centre for Laboratory Medicine, Tampere University Hospital, Tampere, Finland. ${ }^{2}$ Bioinformatics, Institute of Biomedical Technology, University of Tampere and Science Center of Pirkanmaa Hospital District, Tampere, Finland. ${ }^{3}$ School of Health Sciences, University of Tampere, Tampere, Finland. ${ }^{4}$ Department of Urology and Medical School, Tampere University Hospital and University of Tampere, Tampere, Finland.

\section{Authors' contributions}

HM participated in the design of the study, carried out the array and sequencing studies and drafted the manuscript. MS and JI carried out the array data analysis and statistical analyses and revised the manuscript. TI participated in the selection of patients, design of the study and revised the manuscript. MV performed the miRanda studies and revised the manuscript. $\mathrm{HO}$ participated in the design of the study and contributed to the array data analysis. TT is the clinical contributor. TW contributed to study design and coordination and revised the manuscript. JS participated in study design, interpreted the results and critically revised the manuscript. All the authors have read and approved the final manuscript.

\section{Competing interests}

The authors declare that they have no competing interests.

\section{References}

1. Finnish Cancer Registry: Cancer statistics: 2008 [http://www.cancerregistry.fi].

2. Lichtenstein P, Holm NV, Verkasalo PK, Iliadou A, Kaprio J, Koskenvuo M, Pukkala E, Skytthe A, Hemminki K: Environmental and heritable factors in the causation of cancer-analyses of cohorts of twins from Sweden, Denmark, and Finland. N Engl J Med 2000, 343:78-85.

3. Schaid DJ: The complex genetic epidemiology of prostate cancer. Hum Mol Genet 2004, 13(Spec No 1):R103-21.

4. Xu J, Meyers D, Freije D, Isaacs S, Wiley K, Nusskern D, Ewing C, Wilkens E, Bujnovszky P, Bova GS, Walsh P, Isaacs W, Schleutker J, Matikainen M, Tammela T, Visakorpi T, Kallioniemi OP, Berry R, Schaid D, French A, McDonnell S, Schroeder J, Blute M, Thibodeau S, Grönberg H, Emanuelsson M, Damber JE, Bergh A, Jonsson BA, Smith J, et al: Evidence for a prostate cancer susceptibility locus on the $\mathrm{X}$ chromosome. Nat Genet 1998, 20:175-179.

5. Schleutker J, Matikainen M, Smith J, Koivisto P, Baffoe-Bonnie A, Kainu T, Gillanders E, Sankila R, Pukkala E, Carpten J, Stephan D, Tammela T, Brownstein M, Bailey-Wilson J, Trent J, Kallioniemi OP: A genetic epidemiological study of hereditary prostate cancer (HPC) in Finland: frequent HPCX linkage in families with late-onset disease. Clin Cancer Res 2000, 6:4810-4815.

6. Baffoe-Bonnie AB, Smith JR, Stephan DA, Schleutker J, Carpten JD, Kainu T, Gillanders EM, Matikainen M, Teslovich TM, Tammela T, Sood R, Balshem AM, Scarborough SD, Xu J, Isaacs WB, Trent JM, Kallioniemi OP, Bailey-Wilson JE: A major locus for hereditary prostate cancer in Finland: localization by linkage disequilibrium of a haplotype in the HPCX region. Hum Genet 2005, 117:307-316.

7. Stephan DA, Howell GR, Teslovich TM, Coffey AJ, Smith L, Bailey-Wilson JE, Malechek L, Gildea D, Smith JR, Gillanders EM, Schleutker J, Hu P, Steingruber HE, Dhami P, Robbins CM, Makalowska I, Carpten JD, Sood R, Mumm S, Reinbold R, Bonner TI, Baffoe-Bonnie A, Bubendorf L, Heiskanen M, Kallioniemi OP, Baxevanis AD, Joseph SS, Zucchi I, Burk RD Isaacs $W$, et al: Physical and transcript map of the hereditary prostate cancer region at Xq27. Genomics 2002, 79:41-50.

8. Kouprina N, Pavlicek A, Noskov VN, Solomon G, Otstot J, Isaacs W Carpten JD, Trent JM, Schleutker J, Barrett JC, Jurka J, Larionov V: Dynamic structure of the SPANX gene cluster mapped to the prostate cancer susceptibility locus HPCX at Xq27. Genome Res 2005, 15:1477-1486.

9. Kouprina N, Noskov VN, Solomon G, Otstot J, Isaacs W, Xu J, Schleutker J, Larionov $\mathrm{V}$ : Mutational analysis of SPANX genes in families with $\mathrm{X}$-linked prostate cancer. Prostate 2007, 67:820-828.

10. Culbertson MR: RNA surveillance. Unforeseen consequences for gene expression, inherited genetic disorders and cancer. Trends Genet 1999, $15: 74-80$

11. Noensie EN, Dietz HC: A strategy for disease gene identification through nonsense-mediated mRNA decay inhibition. Nat Biotechnol 2001, 19:434-439.

12. Ionov Y, Nowak N, Perucho M, Markowitz S, Cowell JK: Manipulation of nonsense mediated decay identifies gene mutations in colon cancer cells with microsatellite instability. Oncogene 2004, 23:639-645.

13. Fabbri M, Croce CM, Calin GA: MicroRNAs. Cancer J 2008, 14:1-6.

14. Ambs S, Prueitt RL, Yi M, Hudson RS, Howe TM, Petrocca F, Wallace TA, Liu CG, Volinia S, Calin GA, Yfantis HG, Stephens RM, Croce CM: Genomic profiling of microRNA and messenger RNA reveals deregulated microRNA expression in prostate cancer. Cancer Res 2008, 68:6162-6170.

15. Ozen M, Creighton CJ, Ozdemir M, Ittmann M: Widespread deregulation of microRNA expression in human prostate cancer. Oncogene 2008, 27:1788-1793.

16. Baskerville S, Bartel DP: Microarray profiling of microRNAs reveals frequent coexpression with neighboring miRNAs and host genes. RNA 2005, 11:241-247.

17. Cropp CD, Simpson CL, Wahlfors T, Ha N, George A, Jones MS, Harper U, Ponciano-Jackson D, Green TA, Tammela TL, Bailey-Wilson J, Schleutker J: Genome-wide linkage scan for prostate cancer susceptibility in Finland: Evidence for a novel locus on 2 q37.2 and confirmation of signal on 17q21-q22. Int J Cancer 2011

18. Schröder FH, Hugosson J, Roobol MJ, Tammela TL, Ciatto S, Nelen V, Kwiatkowski M, Lujan M, Lilja H, Zappa M, Denis LJ, Recker F, Berenguer A, Määttänen L, Bangma CH, Aus G, Villers A, Rebillard X, van der Kwast T, Blijenberg BG, Moss SM, de Koning HJ, Auvinen A, ERSPC Investigators: 
Screening and prostate-cancer mortality in a randomized European study. N Engl J Med 2009, 360:1320-1328.

19. Enright AJ, John B, Gaul U, Tuschl T, Sander C, Marks DS: MicroRNA targets in Drosophila. Genome Biol 2003, 5:R1.

20. Griffiths-Jones S, Saini HK, van Dongen S, Enright AJ: miRBase: tools for microRNA genomics. Nucleic Acids Res 2008, 36:D154-8.

21. Mendell JT, Sharifi NA, Meyers JL, Martinez-Murillo F, Dietz HC: Nonsense surveillance regulates expression of diverse classes of mammalian transcripts and mutes genomic noise. Nat Genet 2004, 36:1073-1078

22. Pakkanen S, Baffoe-Bonnie AB, Matikainen MP, Koivisto PA, Tammela TL, Deshmukh S, Ou L, Bailey-Wilson JE, Schleutker J: Segregation analysis of 1,546 prostate cancer families in Finland shows recessive inheritance. Hum Genet 2007, 121:257-267.

23. Huusko P, Ponciano-Jackson D, Wolf M, Kiefer JA, Azorsa DO, Tuzmen $\mathrm{S}$, Weaver D, Robbins C, Moses T, Allinen M, Hautaniemi S, Chen Y, Elkahloun A, Basik M, Bova GS, Bubendorf L, Lugli A, Sauter G, Schleutker J, Ozcelik H, Elowe S, Pawson T, Trent JM, Carpten JD, Kallioniemi OP, Mousses S: Nonsense-mediated decay microarray analysis identifies mutations of EPHB2 in human prostate cancer. Nat Genet 2004, 36:979-983.

24. Bloethner S, Mould A, Stark M, Hayward NK: Identification of ARHGEF17, DENND2D, FGFR3, and RB1 mutations in melanoma by inhibition of nonsense-mediated mRNA decay. Genes Chromosomes Cancer 2008, 47:1076-1085

25. Ivanov I, Lo KC, Hawthorn L, Cowell JK, lonov Y: Identifying candidate colon cancer tumor suppressor genes using inhibition of nonsensemediated mRNA decay in colon cancer cells. Oncogene 2007, 26:2873-2884

26. Rossi MR, Hawthorn L, Platt J, Burkhardt T, Cowell JK, lonov Y: Identification of inactivating mutations in the JAK1, SYNJ2, and CLPTM1 genes in prostate cancer cells using inhibition of nonsense-mediated decay and microarray analysis. Cancer Genet Cytogenet 2005, 161:97-103.

27. Cui J, Staples MP, Hopper JL, English DR, McCredie MR, Giles GG: Segregation analyses of 1,476 population-based Australian families affected by prostate cancer. Am J Hum Genet 2001, 68:1207-1218.

28. Lucas S, De Smet C, Arden KC, Viars CS, Lethé B, Lurquin C, Boon T: Identification of a new MAGE gene with tumor-specific expression by representational difference analysis. Cancer Res 1998, 58:743-752.

29. Zmuda JM, Cauley JA, Ferrell RE: Molecular epidemiology of vitamin D receptor gene variants. Epidemiol Rev 2000, 22:203-217.

30. Wolf M, Edgren H, Muggerud A, Kilpinen S, Huusko P, Sorlie T, Mousses S, Kallioniemi O: NMD microarray analysis for rapid genome-wide screen of mutated genes in cancer. Cell Oncol 2005, 27:169-173.

31. Sie L, Loong S, Tan EK: Utility of lymphoblastoid cell lines. J Neurosci Res 2009, 87:1953-9.

32. Mattie MD, Benz CC, Bowers J, Sensinger K, Wong L, Scott GK, Fedele V, Ginzinger D, Getts R, Haqq C: Optimized high-throughput microRNA expression profiling provides novel biomarker assessment of clinical prostate and breast cancer biopsies. Mol Cancer 2006, 5:24.

33. Porkka KP, Pfeiffer MJ, Waltering KK, Vessella RL, Tammela TL, Visakorpi T: MicroRNA expression profiling in prostate cancer. Cancer Res 2007, 67:6130-6135.

34. deVere White RW, Vinall RL, Tepper CG, Shi XB: MicroRNAs and their potential for translation in prostate cancer. Urol Oncol 2009, 27:307-311.

35. Lutter D, Marr C, Krumsiek J, Lang EW, Theis FJ: Intronic microRNAs support their host genes by mediating synergistic and antagonistic regulatory effects. BMC Genomics 2010, 11:224.

36. Mitchell PS, Parkin RK, Kroh EM, Fritz BR, Wyman SK, PogosovaAgadjanyan EL, Peterson A, Noteboom J, O'Briant KC, Allen A, Lin DW, Urban N, Drescher CW, Knudsen BS, Stirewalt DL, Gentleman R, Vessella RL, Nelson PS, Martin DB, Tewari M: Circulating microRNAs as stable bloodbased markers for cancer detection. Proc Natl Acad Sci USA 2008, 105:10513-18.

37. Lawrie $\mathrm{CH}$, Gal S, Dunlop HM, Pushkaran B, Liggins AP, Pulford K, Banham AH, Pezzella F, Boultwood J, Wainscoat JS, Hatton CS, Harris AL: Detection of elevated levels of tumour-associated microRNAs in serum of patients with diffuse large B-cell lymphoma. Br J Haematol 2008, 141:672-675.

38. Chen X, Ba Y, Ma L, Cai X, Yin Y, Wang K, Guo J, Zhang Y, Chen J, Guo X, Li Q, Li X, Wang W, Zhang Y, Wang J, Jiang X, Xiang Y, Xu C, Zheng P, Zhang J, Li R, Zhang H, Shang X, Gong T, Ning G, Wang J, Zen K, Zhang J,
Zhang CY: Characterization of microRNAs in serum: a novel class of biomarkers for diagnosis of cancer and other diseases. Cell Res 2008, 10:997-1006.

\section{Pre-publication history}

The pre-publication history for this paper can be accessed here: http://www.biomedcentral.com/1471-2407/11/327/prepub

\section{doi:10.1186/1471-2407-11-327}

Cite this article as: Mattila et al: NMD and microRNA expression profiling of the HPCX1 locus reveal MAGEC1 as a candidate prostate cancer predisposition gene. BMC Cancer 2011 11:327.

\section{Submit your next manuscript to BioMed Central and take full advantage of:}

- Convenient online submission

- Thorough peer review

- No space constraints or color figure charges

- Immediate publication on acceptance

- Inclusion in PubMed, CAS, Scopus and Google Scholar

- Research which is freely available for redistribution 